\title{
Age Limits in Youth Justice: A Comparative and Conceptual Analysis
}

\author{
Jantien Leenknecht, Johan Put \& Katrijn Veeckmans*
}

\begin{abstract}
In each youth justice system, several age limits exist that indicate what type of reaction can and may be connected to the degree of responsibility that a person can already bear. Civil liability, criminal responsibility and criminal majority are examples of concepts on which age limits are based, but whose definition and impact is not always clear. Especially as far as the minimum age of criminal responsibility (MACR) is concerned, confusion exists in legal doctrine. This is apparent from the fact that international comparison tables often show different MACRs for the same country. Moreover, the international literature often seems to define youth justice systems by means of a lower and upper limit, whereas such a dual distinction is too basic to comprehend the complex multilayer nature of the systems. This contribution therefore maps out and conceptually clarifies the different interpretations and consequences of the several age limits that exist within youth justice systems. To that extent, the age limits of six countries are analysed: Argentina, Austria, Belgium, the Netherlands, New Zealand and Northern Ireland. This legal comparison ultimately leads to a proposal to establish a coherent conceptual framework on age limits in youth justice.
\end{abstract}

Keywords: youth justice, age limits, minimum age of criminal responsibility, age of criminal majority, legal comparison

\section{Introduction}

Age limits in youth justice systems are essential to determine what type of reaction a juvenile offender can be subject to. International legal doctrine traditionally distinguishes between the minimum age of criminal responsibility (MACR) and the age of criminal majority (ACM) to define the scope of the youth justice system. Whereas the ACM is fixed at the age of 18 in almost every country, ${ }^{1}$ much more diversity can be found with regard to the MACR, as proven by the several age limits

* Jantien Leenknecht is PhD Fellow of the Research Foundation Flanders (FWO) at KU Leuven, Institute of Social Law and Leuven Institute of Criminology. Johan Put is Full Professor at KU Leuven, Institute of Social Law and Leuven Institute of Criminology. Katrijn Veeckmans is PhD Fellow at KU Leuven, Institute of Social Law and Leuven Institute of Criminology.

1. OECD - Social Policy Division - Directorate of Employment, Labour and Social Affairs, 'PF1.8 Legal age threshold regarding transition from childhood to adulthood' (2016), at 1-2, www.oecd.org/els/family/ PF_1_8_Age_threshold_Childhood_to_Adulthood.pdf; I. Weijers and tables in the international comparative literature. ${ }^{2}$ In past years, efforts have been made to clarify what the MACR and its implications are and how it should be distinguished from the ACM. ${ }^{3}$ However, other relevant age limits exist within a youth justice system that restrict the number of possible reactions, determine the maximum duration or severity of a reaction or determine which court or institution is competent. A dual distinction between the MACR and the ACM is therefore too simple to comprehend the complex multilayer nature of youth justice systems. Moreover, international comparative tables sometimes show different MACRs for the same country, ${ }^{4}$ which suggests that the concept of 'criminal responsibility' is interpreted in different ways and the ambiguity remains.

This contribution analyses the age limits of six countries with divergent age limits. Three countries, two of which are European and one non-European, were selected because they have a low MACR according to the prevailing comparative tables: the Netherlands, Northern Ireland and New Zealand. The other three selected countries, also two European and one non-European, have a high MACR according to those tables: Belgium, Austria and Argentina. By mapping out and conceptually clarifying the different interpretations and consequences of the several age limits within these countries, the article aims to achieve greater clarity and conceptual coherence with regard to age limits in youth justice systems. This article therefore builds, to some extent, on the more extensive comparative approach that is used in the comparative analyses in F. Dünkel, J. Grzywa,

F. Imkamp (eds.), Jeugdstrafrecht in internationaal perspectief (2008), at 270.

2. D. Cipriani, Children's Rights and the Minimum Age of Criminal Responsibility: A Global Perspective (2009), at 187-224; F. Dünkel, J. Grzywa, P. Horsfield and I. Pruin (eds.), Juvenile Justice Systems in Europe: Current Situation and Reform Developments - Vol. 4 (2011), at 1847; Weijers and Imkamp, above n. 1, at 271; M.F. Aebi, M.M. Tiago and C. Burkhardt, 'SPACE I - Council of Europe Annual Penal Statistics: Prison populations. Survey 2015.' (2016), at 57, http://wp.unil.ch/ space/files/2017/04/ SPACE_I_2015_FinalReport_161215_REV170425.pdf.

3. Cipriani, above n. 2; L.S. Abrams, S.P. Jordan and L.A. Montero, 'What Is a Juvenile? A Cross-National Comparison of Youth Justice Systems', 18(2) Youth Justice 111-130 (2018).

4. In the following comparative tables, for instance, the Belgian MACR is 18,16 or 12 respectively: Dünkel et al., above n. 2, at 1793; N. Hazel, 'Cross-national Comparison of Youth Justice' (2008), at 30, https:// dera.ioe.ac.uk/7996/1/Cross_national_final.pdf; Cipriani, above n. 2, at 191. The same tables set the Estonian MACR at 7, 14 and 16 respectively: Cipriani, above n. 2, at 197; Dünkel et al., above n. 2, at 1793; Hazel, above n. 4, at 31. 
P. Horsfield and I. Pruin (eds.), Fuvenile Fustice Systems in Europe: Current Situation and Reform Developments Vol 4 (2011) 1539-1898. However, this article zooms in only from one particular point of view, namely age limits, and goes beyond merely analysing the differences between national systems to introduce a conceptual framework.

The limited size of the article is inevitably accompanied by choices that result in restrictions of the scope and, consequently, content limitations. First of all, this contribution examines what we call 'offence-oriented reactions', which are reactions that can be imposed from general criminal law or youth justice ${ }^{5}$ law to common offences. Reactions from administrative, civil or youth care law are consequently excluded from the scope of this article because they do not react to common offences or do not primarily aim at reacting to the offence but at treating the underlying issues of the juvenile offender. Second, the focus in this article is on the age limits of youth justice systems and therefore does not go into detail on the legal and technical conditions that accompany them. ${ }^{6}$ The relevant legal provisions are always mentioned, so the reader can carefully consult the conditions to be fulfilled. Lastly, this contribution is an exploratory study that exposes the multilayered structure of age limits and, accordingly, proposes a new classification. However, the new classification has been tested only in six, albeit diverse, countries, so a verification in additional countries will be indispensable to check the accuracy of the framework and to refine it where necessary.

\section{Comparison of Age Limits Across Six Countries}

\subsection{The Netherlands}

Unlike many other countries, no separate statutory regulation on youth justice exists in the Netherlands. Instead, the Wetboek van Strafrecht (Penal Code, hereinafter PC) and the Wetboek van Strafvordering (Code of Criminal Procedure, hereinafter CCP) formulate deviating provisions for juvenile offenders, ${ }^{7}$ under which minors from the age of 12 at the time of the offence can

5. UN Committee on the Rights of the Child, 'General Comment No. 24 (201x), Replacing General Comment No. 10 (2007) on Children's Rights in Juvenile Justice', at 4, https://www.ohchr.org/Documents/ HRBodies/CRC/GC24/GeneralComment24.pdf: Youth justice refers to legislation, norms and standards, procedures, mechanisms and provisions, institutions and bodies specifically applicable to children considered as offenders. Although the UNCRC still uses the notion 'juvenile justice', it acknowledges and encourages the trend towards using terms such as 'youth justice' and 'child justice'.

6. Whenever expressions such as 'between the age of 10 and 14', 'from 10 until 14 years old' or 'a child aged from 10 to 14' are used, only the ages $10,11,12$ and 13 are included. The age that is mentioned last, in casu 14 , is excluded.

7. A.M. van Kalmthout and Z. Bahtiyar, 'The Netherlands', in F. Dünkel, J. Grzywa, P. Horsfield and I. Pruin (eds.), Juvenile Justice Systems in Europe: Current Situation and Reform Developments - Vol. 2 (2011) 911, at 912. be prosecuted. ${ }^{8}$ With regard to minors who commit an offence under the age of 12 , an irrebuttable presumption of irresponsibility exists. The behaviour of such minors is dealt with under youth care law, because they are considered to have 'growing and parenting problems, psychological problems and disorders'. The Dutch legislature deliberately chose to link the lower limit to criminal prosecution, and not to criminal investigation, because he still wants it to be possible that investigative actions are carried out with regard to minors who are suspected of having committed a crime, even if they have not reached the age of $12 .{ }^{9}$ That is why Article 487 CCP allows police officers inter alia to arrest and interrogate a minor or to enter and search his or her place. ${ }^{10}$

The general provisions of adult criminal law apply as soon as the person has reached the age of 18 years at the time of the offence. ${ }^{11}$ However, there are two exceptions to this principle. ${ }^{12}$ First, Article $77 \mathrm{~b}$ PC enables the youth court judge to impose a sentence from the general criminal law instead of one of the deviating reactions in the youth justice provisions, but with the exclusion of life imprisonment. ${ }^{13}$ In addition to the condition that a minor must be at least 16 years old at the time of the commission of the offence, the provisions sets out three alternative criteria for lowering the upper limit: the seriousness of the offence committed, the personality of the offender or the circumstances under which the offence was committed. ${ }^{14}$ Even though a minor becomes subject to the provisions of substantive criminal law under this exception, the rules of investigation, prosecution and trial are still those of youth justice. ${ }^{15}$

The second exception is the extended application of the deviating provisions on youth justice to persons aged between 18 and 23 years (the 'young adults') at the time of the offence. ${ }^{16}$ The criminal court judge can use this possibility when one of two alternative criteria is met, namely the personality of the offender or the circumstances under which the offence was committed. Again, the exception relates only to the type of reactions available to the judge and not to the procedural rules applicable, except for the mandatory personal appearance of the young adult at the trial. ${ }^{17}$ This means that the young adult is still tried in accordance with the common criminal procedure provisions but is subject to one of the reactions provided in the youth justice provisions, which is then executed in a young offenders institution.

Art. 77a PC; Art. 486 CCP; J. uit Beijerse, Jeugdstrafrecht: Beginselen, wetgeving en praktijk (2019), at 48; Weijers and Imkamp, above n. 1, at 267.

9. uit Beijerse, above n. 8, at 49 .

10. G. De Jonge, 'The Netherlands', in V. Patanè (ed.), European Juvenile Justice Systems (2007) 425, at 427; Cipriani, above n. 2, at 209

11. Art. $77 \mathrm{a}$ PC.

12. Weijers and Imkamp, above n. 1, at 267.

13. Art. $77 b(2) P C$.

14. Art. $77 \mathrm{~b}(1) P C$.

15. Art. 488(2) CCP; uit Beijerse, above n. 8, at 54.

16. Art. $77 \mathrm{c} \mathrm{PC}$.

17. uit Beijerse, above n. 8, at 59 and 68; van Kalmthout and Bahtiyar, above n. 7 , at 937 
Nevertheless, both the HALT measure ${ }^{18}$ and community service ${ }^{19}$ can be imposed only on juvenile offenders who have not reached the age of 18 at the time of the offence.

The existence of these two exceptions indicates that the Dutch legislature is convinced that young people do not all develop at the same pace ${ }^{20}$ and that therefore a fixed upper limit for applying youth justice reactions is not an accurate reflection of reality. That is why the boundary between the youth justice system and the adult justice system was eased as from 1 April 2014, with the introduction of adolescent criminal law (ACL) for persons between 16 and 23 years old. ${ }^{21}$ Youth justice and criminal justice continue to exist side by side, so ACL is not a separate, new form of criminal law, but merely creates a closer link between the two systems and stimulates a flexible use of both systems. ${ }^{22} \mathrm{By}$ adapting the conditions of youth justice reactions and increasing the emphasis on forensic advice provided by forensic experts, the judge has more possibilities to take into account the adolescent's stage of development and therefore impose a more appropriate reaction. ${ }^{23}$

Article 77(h) PC lists all reactions that can be imposed when a minor is tried on the basis of the youth justice system. The reactions are not linked to specific age requirements, which means that they can be imposed on minors from the age of 12 . The duration of custodial sentences, on the other hand, may depend on age. Juvenile offenders under 16 years old can be subject only to custodial sentences with a maximum duration of one year, whereas the maximum duration for 16- and 17year-olds is two years. ${ }^{24}$ Both sentences are served in a young offenders institution. ${ }^{25}$ In addition, a person may be subject to a measure of 'placement in a judicial institution for young offenders' (PIY-measure). This measure can be compared to an in-patient of hospital order for adults ${ }^{26}$ and is therefore accompanied with strict, cumulative conditions. ${ }^{27}$ The PIY-measure lasts for a period of three years, ${ }^{28}$ but the public prosecutor can ask for an extension of two years, up to a maximum of seven years. ${ }^{29}$

Ministerie voor Veiligheid en Justitie, 'Adolescentenstrafrecht: Aanpak met perspectief' (2014), at 7, https://wegwijzerjeugdenveiligheid.nl/ fileadmin/user_upload/Bestanden/Onderwerpen/

Adolescentenstrafrecht/Brochure-adolescentenstrafrecht.pdf.

19. Art. 771(4) PC.

20. Ministerie voor Veiligheid en Justitie, above n. 18, at 5 .

21. Wet van 27 november 2013 in verband met de invoering van een adolescentenstrafrecht, Stb. 2013, 485

22. Ministerie voor Veiligheid en Justitie, above n. 18, at 6 .

23. L.J.C. Prop, A.M. van der Laan, C.S. Barendregt, M.G.C.J. Beerthuizen and Ch. van Nieuwenhuizen, 'Adolescentenstrafrecht: Kenmerken van de doelgroep, de strafzaken en de tenuitvoerlegging' (2018), at 75, https://www.wodc.nl/binaries/Cahier\%202018-9_2460g_Volledige \%20tekst_tcm28-328944.pdf.

24. Art. 77i PC; van Kalmthout and Bahtiyar, above n. 7, at 913.

25. Art. 8(e) Beginselenwet Jusitiële Jeugdinrichtingen.

26. van Kalmthout and Bahtiyar, above n. 7, at 946.

27. Art. 77s(1) PC

28. Art. $77 \mathrm{~s}(7) \mathrm{PC}$.

29. Arts. 77t(1) and (2) PC.

\subsection{Northern Ireland}

Under youth justice, minors in Northern Ireland can be called to account for their actions at a very young age, as is typical of common law systems. Section 3 of the Criminal Justice (Children) (Northern Ireland) Order (hereinafter CJO), more specifically, provides for an irrebuttable presumption that children under the age of 10 cannot be guilty of an offence. The criminal behaviour of minors under the age of 10 can only be the subject of measures under child welfare legislation, namely the Children Order $1995 .{ }^{30}$ In that case, the child has to be 'in need' or is 'likely to suffer significant harm'. ${ }^{31}$

The upper limit has been raised from the age of 17-18 since the Justice (Northern Ireland) Act (hereinafter JA) of 2002..$^{32}$ That means that persons 18 and over are tried and punished in accordance with adult criminal law provisions. Northern Ireland does not have any exceptions that raise the upper age limit with regard to young adults. However, the upper limit can be lowered in the very exceptional case that a minor has been charged with homicide or has been co-accused with an adult. ${ }^{33}$ Although rare, it is therefore possible for a minor to be transferred to an adult court and consequently be subject to adult criminal law from the age of 10 . However, in the case of co-accusation with an adult, the juvenile offender can be tried in the adult court only as far as the guilt is concerned, since the case is referred back to the youth court for sentencing when he or she is found guilty. ${ }^{34}$

In terms of sentencing practices, young adults between 16 and 21 (and exceptionally 24) years old who have been sentenced to imprisonment on the basis of a young offenders centre order have to serve their custodial sentence in an adapted detention institution, namely a young offenders centre. ${ }^{35}$ The maximum duration of detention in a young offender centre is four years, but when the young adult reaches 21 years of age, he may be transferred to an adult prison. ${ }^{36}$ The person is in any case automatically transferred to adult prison at the age of $24 .{ }^{37}$ In addition, minors between 10 and 17 years old can be subject to a juvenile justice centre order and are committed to a juvenile justice centre to serve their cus-

30. X, 'A Review of the Youth Justice System in Northern Ireland' (2011), at 21, https://restorativejustice.org.uk/sites/default/files/resources/files/ Report\%20of\%20the\%20Youth\%20Justice\%20System\%20in\%20 Northern\%20Ireland.pdf; D. O'Mahony, 'Northern Ireland', in F. Dünkel, J. Grzywa, P. Horsfield and I. Pruin (eds.), Juvenile Justice Systems in Europe: Current Situation and Reform Developments - Vol. 2 (2011) 957, at 961.

31. Section 17, $5062,63,6566,129$ Child Order 1995

32. Section $63 \mathrm{JA}$ juncto scheme 11, section $17 \mathrm{JA}$. Section (2) (2) CJO now defines an adult as 'a person who has attained the age of 18' and a child as 'a person who is under the age of 18 '.

33. Section 29 (1) CJO; O'Mahony, above n. 30, at 976

34. Section 29 (2) (b) (ii) and $32 \mathrm{CJO}$.

35. Section 5 (1) Treatment of Offenders Act (Northern Ireland) 1968

36. Section 5 (1) (ii) Treatment of Offenders Act (Northern Ireland) 1968; O'Mahony, above n. 30, at 971.

37. Section 8 (1) and (2) Treatment of Offenders Act (Northern Ireland) 1968. 
todial sentence. ${ }^{38}$ This is also the case for 17 -year-olds in two specific situations. ${ }^{39}$ The duration of a juvenile justice centre order is six months to two years. ${ }^{40}$ In case the court has made a custody care order with regard to a minor, the use of detention in a juvenile justice centre is restricted to juvenile offenders at least 14 years old. ${ }^{41}$ Children between 10 and 14 years old who are subject to a custody care order are accommodated in the child care system instead. ${ }^{42}$

Finally, the application of certain reactions under the Northern Irish youth justice system requires a certain minimum age. Community services and probation, for example, can be imposed only on juvenile offenders aged 16 or older. ${ }^{43}$ Moreover, the level of fines is higher for minors who have reached the age of $14,{ }^{44}$ and the child only has to pay the fine itself, instead of his or her parent or guardian, from the age of $16 .{ }^{45}$

\subsection{New Zealand}

As a former British colony, the legislation of New Zealand is remarkably influenced by the laws of the UK. ${ }^{46}$ Following the English laws, the age below which a child cannot be convicted of an offence was set at 7 in New Zealand. ${ }^{47}$ However, in 1961 (post colonisation) it was raised to 10 years. ${ }^{48}$ Offenders were considered minors until the age of 17 only until recently: ${ }^{49}$ the upper age limit was revised to 18 years since the Children's and Young People's Well-being Act 1989 (CYW Act) was passed on 13 July 2017 and came into force on 1 July $2019 .^{50}$

In the youth justice system of New Zealand a conceptual distinction is used: 'children' are defined as those under the age of 14. Minors between the age of 14 and 18 are called 'young persons'. ${ }^{51}$ In general, children are subject to the care and protection provisions of the CYW Act, while young persons are covered by the youth justice provisions. ${ }^{52}$ The youth justice system in New Zealand has a threefold structure.

1. According to section 21 of the Crimes Act, minors under the age of 10 cannot be convicted of an offence. Children below that age are dealt with

38. Section 13 (1) (a) CJO.

39. Section $39(3 \mathrm{~A}) \mathrm{CJO}$.

40. Section 39 (2) CJO.

41. Section 44A (8) and 44C (1) CJO

42. D. O'Mahony and C. Campbell, 'Mainstreaming Restorative Justice for Young Offenders through Youth Conferencing: The Experience of Northern Ireland', in J. Junger-Tas and S. H. Decker (eds.), International Handbook of Juvenile Justice (2006) 93, at 99.

43. Section 3C (2) CJO; X, above n. 30, at 26.

44. Section 34, 41 (2) (a) and $44 \mathrm{~F}(3)$ and (4) CJO

45. Section 35 (1) and 41 (2B) CJO.

46. A. Morris, 'Youth Justice in New Zealand', 31 Crime \& Justice 243, at 246 (2004).

47. Ibid., at 247

48. Section 21 Crimes Act, No. 43.

49. Section 272 Children, Young Persons and Their Families Legislation Act 1989, No. 3.

50. Section $272 \mathrm{CYW}$ Act.

51. Section 2 (1) CYW Act.

52. A.J. Becroft, 'Children and Young People in Conflict with the Law: Asking the Hard Questions', (57) Juvenile \& Family Court Journal 1, at 8 (2006); Morris, above n. 46, at 260. under the care and protection system. ${ }^{53} \mathrm{~A}$ broad definition of 'a child or young person in need of care and protection' is given in section 14 CYW Act.

2. Likewise, children between the age of 10 and 14 cannot be charged with a crime. However, this presumption of irresponsibility can be rebutted when 'he or she knew that the act or omission was wrong or that it was contrary to law'. 54 This second category of minors consists of two subcategories. ${ }^{55}$ First of all, children aged 10 and 11 can be prosecuted only in case of murder or manslaughter. After the pretrial in the youth court, a child charged with one of the aforementioned offences is sentenced in an adult criminal court (high court) according to adult law. ${ }^{56}$ The second subcategory consists of children of 12 or 13 years of age, who can be prosecuted not only for murder or manslaughter, but also for other serious offences. Again, the trial of children charged with murder and manslaughter takes place in high court, whereas children prosecuted for other serious offences are sentenced in a youth court. ${ }^{57}$ When the aforementioned conditions are not fulfilled and the presumption of irresponsibility cannot be rebutted, children who commit a crime are covered by the care and protection system. ${ }^{58}$

3. The third group consists of offenders between 14 and 18 years old. These young persons can be charged with any criminal offence under the youth justice system, except for (a) murder and manslaughter, (b) some serious offences for which the minor asks trial by jury, (c) when the minor is charged jointly with another person and will have a trial by jury and (d) for traffic offences not punishable by imprisonment. With regard to these four types of offences, a minor between the age of 14 and 18 is automatically tried in an adult court (district or high court) and receives an adult sentence. ${ }^{59}$ Apart from this automatic transfer, a judicial transfer is possible as well: the youth court has the discretion to decide whether or not to transfer a 15 -year-old or a 14-year-old who committed certain serious offences (other than the four aforementioned offences) to the district court or high court. ${ }^{60}$ In adult court, the young age of the offender can be considered as a mitigating circumstance. ${ }^{61}$ On reaching the age of 18 , offenders will always be held responsible in adult criminal courts under adult criminal law.
53.
Section 14 CYW; Becroft, above n. 52, at 8.

Section 22 of the Crimes Act.

Section 272 CYW Act.

Section 272(2) and 275 (2)(b) CYW Act; F. Chye, 'When Children Kill: The Age of Criminal Responsibility and Criminal Procedure in New Zealand', 2 New Zealand Law Students Journal 837, at 841 (2012).

Section $272(2 \mathrm{~A})$ and 272A CYW Act.

Becroft, above n. 52, at 8 .

Section 272, 273 and 275 CYW Act.

Section 283(0) and 285(6) CYW Act.

Section 9(2)(a) Sentencing Act 2002. 
Since the New Zealand youth justice system is focused on diversion, family participation in decision-making, restorative justice and victim involvement, the youth court is less influential than in other countries. ${ }^{62}$ The set of reactions, which are called 'orders' to restrain the stigmatising effect of a sanction, seems rather mild. Moreover, the imposed orders expire when the minor attains the age of $19 .{ }^{63}$ Children or young persons who are subject to a 'supervision with residence order' are detained in a specialised youth justice residence, ${ }^{64}$ while (exceptionally) minors who are transferred to adult court can be detained in prison. ${ }^{65} \mathrm{~A}$ supervision with residence order can be imposed for a minimum of three months and no longer than six months. Finally, an order to pay the costs of the prosecution needs to be executed only by the minor, instead of his parents, from the age of 16.66

\subsection{Belgium}

Belgium is a federal state, consisting of three communities: the Flemish, French and German-speaking Community. ${ }^{67}$ Until recently, youth justice was mainly a federal competence, regulated by the Feugdbeschermingswet (Youth Protection Act). ${ }^{68}$ However, due owing to the sixth state reform of 2014, the communities have been empowered to regulate the judicial reaction (nature, criteria, content and hierarchy) towards juvenile delinquency on their territory. ${ }^{69}$ The procedural issues remain a competence of the federal state. ${ }^{70}$ In concrete terms this means the Flemish, French and Germanspeaking Community as well as the Common Community Committee of Brussels (CCC) ${ }^{71}$ can enact their own legislation regarding youth justice. Since the Germanspeaking Community has not yet issued its own legislation in this regard, this article will focus on the decrees of the Flemish and French Community and the statute of the CCC.

On 15 February 2019 the Feugddelinquentiedecreet (Flemish Decree on Juvenile Delinquency, hereinafter Flemish Decree) was ratified. ${ }^{72}$ The Flemish Decree applies to minors who are at least 12 years old at the time of the offence. ${ }^{73}$ By virtue of an irrebuttable pre-

62. A. Morris and G. Maxwell, 'Reforming Juvenile Justice: The New Zealand Experience', 77(2) The Prison Journal 125, at 127 (1997).

63. Section 296 CYW Act.

64. Section 283(n), 311, 361(h) and 365 CYW Act.

65. Section 18 Sentencing Act 2002

66. Section 283 (e) and ( $f$ ) CYW Act.

67. Art. 2 Federal Constitution of 17 February 1994

68. Wet van 8 April 1965 betreffende de jeugdbescherming.

69. E. Dumortier, J. Christiaens and A. Nuytiens, 'Belgium', in S.H. Decker and N. Marteache (eds.), International Handbook of Juvenile Justice (2016) 239, at 240.

70. Ibid

71. Brussels is a bilingual territory (Dutch-speaking and French-speaking). The powers concerning this territory are divided between the Flemish Community, the French Community and the Common Community Committee. Regarding juvenile justice, it is the Common Community Committee that has the jurisdiction to enact legislation.

72. Decreet van 15 februari 2019 betreffende het jeugddelinquentierecht; J. Put and J. Leenknecht (eds.), Het Vlaamse jeugddelinquentierecht (2019).

73. Art. 2(10) and Section 4(1) Flemish Decree. sumption of irresponsibility, ${ }^{74}$ children under the age of 12 can be covered by the youth care system only if they are in an 'alarming situation'. ${ }^{75}$

The upper limit is set at 18 years, so offenders aged 18 or older are held responsible under adult criminal law. ${ }^{76}$ However, there are some exceptions to this general rule:

- Offenders aged 16 or 17 can be transferred to a special chamber of the youth court, ${ }^{77}$ where he or she is treated according to adult criminal law. Certain conditions must be fulfilled before the (regular) youth court can decide whether or not the minor should be transferred. ${ }^{78}$

- When a minor aged 16 or 17 commits a traffic offence, he or she will automatically be prosecuted in adult criminal court, except when the latter considers a reaction-based on the Flemish Decree more adequate or when this traffic offence is connected to another offence. ${ }^{79}$

As far as the possible reactions to the offence are concerned, custodial measures or sentences are always executed in specialised institutions. They can be imposed only on offenders who were at least 14 years old at the time of the offence (even 16 with respect to the custodial sentence 'long detention'). Only exceptionally can these reactions apply to minors aged 12 or 13 at the time of the offence. ${ }^{80}$ At the age of 23 , the measures or sanctions imposed by the youth court are terminated. ${ }^{81}$ Again, this should be nuanced: the duration of the 'long detention' reaction depends on the age of the offender, causing a layered system in which an offender aged 12 or 13 at the time of the offence can be subject to long detention for a maximum of two years, a 14- or 15-year-old for a maximum of five years and a 16- or 17-year-old for a maximum of seven years. ${ }^{82}$ Consequently, a long detention imposed on an offender aged 17 at the time of the offence can be carried out until the age of 25 . In addition, the long detention reaction can be combined with preventive custody of (maximum) ten years, which begins as soon as the long detention is finished. ${ }^{83}$ The preventive custody takes place in a youth facility.

The French community adopted the Décret portant le code de la Prévention, de l'Aide à la jeunesse et de la Protection de la Feunesse (Decree on Prevention, Youth Aid and Youth Protection) on 18 January 2018 (French Community Decree, hereinafter FCD) ${ }^{84}$ Contrary to the Flemish Decree, the FCD remains silent on the lower age limit. Even more so, article 101 (4) rules that minors under the age of 12 at the time of the offence can

\footnotetext{
Art. 4(2) Flemish Decree.

Art. 2(1)(54) Decree integral youth care.

Art. 2(10) Flemish Decree.

Serious offences will be dealt with in the court of assizes.

Art. 38 Flemish Decree.

Art. 5 Flemish Decree.

Arts. 35, 36 and 37 Flemish Decree.

Art. 6 Flemish Decree.

Art. 37 Flemish Decree.

Art. 37(8) Flemish Decree.

84. Décret du 18 janvier 2018 portant le code de la prévention, de l'aide à la jeunesse et de la protection de la jeunesse.
} 
be subject to certain provisional measures (supervision, guidance and specialised guidance). As regards the final measures, article 109 states that a child below the age of 12 can be subject only to the measure of reprimand. These two provisions indicate that a child below the age of 12 can be held criminally responsible, but the FCD does not specify what the ultimate lower age limit should be, so that the latter remains undefined.

With regard to the upper age limit, the FCD states that it applies to offenders below the age of $18 .{ }^{85}$ The two exceptions of the Flemish Decree concerning the upper age limit can also be found in the FCD (i.e. transfer to a special chamber of the youth court ${ }^{86}$ and traffic offences ${ }^{87}$ ).

As to the measures to be imposed, custodial sentences (which are executed in specialised institutions) can be applied only if the minor was aged 14 or older at the time of the offence. ${ }^{88}$ Only exceptionally can a 12 - or 13-year-old be detained. ${ }^{89}$ Provisional measures can be imposed or upheld until the offender is 20 years old. ${ }^{90}$ The final measures continue to be carried out until the age of 18 , and exceptionally until the age of $20 .{ }^{91}$

The Ordonnantie betreffende de Feugdhulpverlening en Feugdbescherming of the CCC (Statute on Youth Care and Child Protection) ${ }^{92}$ was ratified on 16 May 2019 and applies to offenders who are at least 12 years old at the time of the offence. ${ }^{93}$ As in the Flemish Decree, an irrebuttable presumption of irresponsibility exists towards children under the age of $12,{ }^{94}$ and once the age of 18 has been reached, the offender is tried in the adult criminal court. ${ }^{95}$ Likewise, the same exceptions as in the Flemish Decree and the FCD concerning the transfer of 16- or 17-year-olds to a special chamber of the court ${ }^{96}$ and traffic offences ${ }^{97}$ apply in Brussels.

Again, there are some age limits concerning the reactions on the criminal offence. First, not every judicial reaction is applicable to offenders of 12 years. For instance, custodial sentences can be imposed when the minor is at least 14 years old (in exceptional circumstances when the minor is 12 or 13 years old), ${ }^{98}$ whereas working with a view to paying damages to the victim can be ordered only when the child is at least 15 years old. ${ }^{99}$ Furthermore, imposing or upholding provisional measures is possible until the age of $20 .{ }^{100}$ Final measures, on the other hand, last until the minor turns 18 .

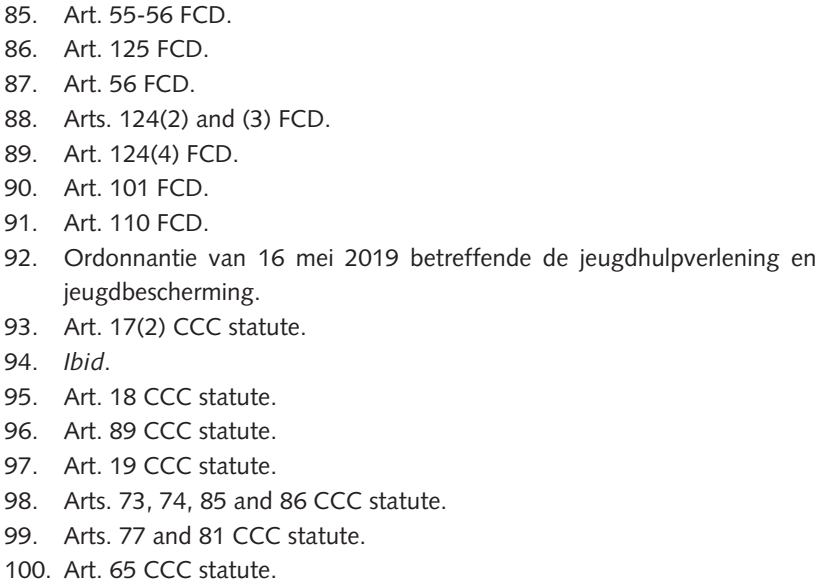

However, the measures can exceptionally sustain until the offender reaches the age of $23 .{ }^{101}$ The decision of a reprimand, lastly, is possible any time, regardless of the age of the offender. ${ }^{102}$

\subsection{Austria}

Austrian youth justice is regulated by a separate law, i.e. the Fugendgerichtsgesetz (Juvenile Court Act, hereinafter JCA), but the Strafgesetzbuch (Penal Code, hereinafter PC) and the Strafprozeßordnung (Code of Criminal Procedure, hereinafter CCP) apply when the JCA does not provide for a specific youth justice rule. Influenced by Soviet law, ${ }^{103}$ the provisions of the JCA apply to minors between 14 and 18 years old. ${ }^{104}$ As a consequence, minors under the age of 14 are not punishable ${ }^{105}$ and can only be subject to measures under the Bundes Kinder- und Fugendhilfegesetz (Children and Youth Services Act, hereinafter CYSA), which apply if the welfare of the child is not guaranteed with regard to the care and upbringing. ${ }^{106}$ Although minors may, in principle, be prosecuted for their committed offence from the age of 14, there are two exceptions on the basis of which such a minor remains unpunished. The first exception is the so-called 'delayed maturity', when the minor is not yet mature enough to see the injustice of the act or to act in accordance with insight. ${ }^{107}$ The second exception concerns minors who commit an offence before reaching the age of 16 but have no serious fault on their part and against whom no special reasons exist for the application of the youth justice system in order to prevent recidivism ('moderate misdemeanours'). ${ }^{108}$ The Austrian youth justice system therefore applies in a gradual manner according to the minor's capacity to assess the consequences of his or her actions.

The upper limit on the other hand, is strictly set at the age of $18 .^{109}$ This means that minors can under no circumstances be subject to adult criminal law; no system of transfer to adult criminal law exists. Concomitantly, the maximum duration of custodial sentences in the youth justice system is much higher: as a general rule, the maximum sentences under adult criminal law are reduced by half, ${ }^{110}$ but life imprisonment is replaced by a custodial sentence of 1 to 15 years for minors aged at least 16 or of 1 to 10 years for minors between 14 and 16 years old at the time of the offence. ${ }^{111}$ An imprisonment from 10 to 20 years is also replaced by a detention from 6 months to 10 years. ${ }^{112}$ The age at which a convict starts to serve his or her custodial sentence is decisive in determining whether he is covered by the juve-

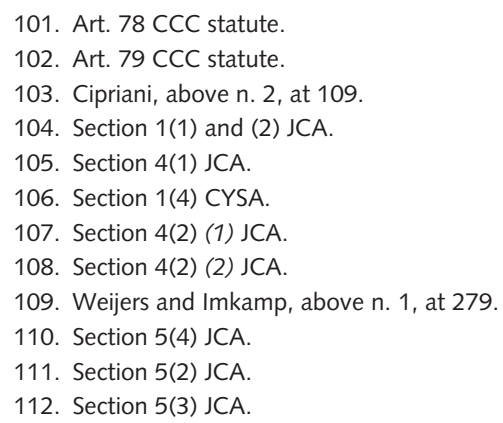


nile or adult detention system. ${ }^{113}$ Only convicts that have not reached the age of 18 are incarcerated in an institution for juvenile detention. However, persons up to 22 years old can also begin to serve their sentence in a juvenile detention centre, if no negative or other detrimental effects on juvenile convicts is to be expected. ${ }^{114}$ In certain circumstances, the convict can even remain subordinated to juvenile detention until he or she turns 24 in order to serve his or her sentence, but under no circumstances later than the age of $27 .{ }^{115}$ In the latter case, the person has to be transferred to a regular prison. Since the upper limit was lowered from 19 to 18 years old in 2001, a separate criminal law for persons between 18 and 21 years old ('young adults') was created as a compensation. ${ }^{116}$ The compensation is, however, limited to declaring most of the procedural provisions applicable to young adults and does not constitute substantive law regulations for this age group. ${ }^{117}$ Young adults are consequently still subject to the range of sentences of adult criminal law as laid down in the PC. Section 34 PC nevertheless refers to section $19 \mathrm{JCA}$, which states that young adults cannot be subject to custodial sentences exceeding a duration of 15 years. As a consequence, custodial sentences exceeding a duration of 15 years and life imprisonment are excluded as a possible penalty. Moreover, section 36(1)(1) PC includes the commission of an offence between the ages of 18 and 21 as a mitigating circumstance.

Austria has no separate institutionalised youth court, which means that youth cases are dealt with under district courts or regional courts for criminal matters. ${ }^{118}$ Within these courts, however, departments for youth cases have been established. They are composed of specialised judges and prosecutors and deal with offences committed by 14 - to 21 -year olds. ${ }^{119}$ Section 30 JGG, more specifically, stipulates that the judges and prosecutors in charge of a youth case must have pedagogical skills and some expertise with regard to psychology and social work. In addition, where a court of lay judges or a jury is to decide on the youth case, there always has to be a judge who is or has been active in the teaching profession, as educators or in public or private child and youth welfare or youth care. ${ }^{120}$ The type of court and its composition (single judge or professional and lay judges) that deals with the specific case depends on the qualification of the offence and the possible reaction according to the JGG. ${ }^{121}$ The regional court, for

113. K. Bruckmüller, A. Pilgram and G. Stummvoll, 'Austria', in F. Dünkel, J. Grzywa, P. Horsfield and I. Pruin (eds.), Juvenile Justice Systems in Europe: Current Situation and Reform Developments - Vol. 1 (2011) 41 , at 85.

114. Section 55(3) (1) JCA

115. Section 55(3) (2) JCA.

116. K. Bruckmüller, 'Austria: A Protection Model', in J. Junger-Tas and S. H. Decker (eds.), International Handbook of Juvenile Justice (2006) 263, at 264; Weijers and Imkamp, above n. 1, at 281.

117. Section 46a JCA; Bruckmüller et al., above n. 113, at 43 .

118. Bruckmüller et al., above n. 113 , at 57

119. Bruckmüller, above n. 116 , at 228-229

120. Section 28 JGG

121. E. Coutteel, K. Herbots, S. Lembrechts, J. Put, N. Sporen, and A. Versweyvelt, 'Rapport 5. Jeugdrechtsystemen in vergelijking' (2015), at instance, adjudicates cases as a jury court with regard to offences committed by persons under the age of $21 .{ }^{122}$

\subsection{Argentina}

Argentina has enacted legislation that (partly) regulates the status, rights and obligations of minor delinquents, despite the lack of a formal, separate youth justice system. ${ }^{123}$ The main sources that concern juvenile offenders are Ley 22.278 Régimen Penal de la Minoridad (Act 22.278 on Youth Justice) ${ }^{124}$ and Ley 26.061 Protección Integral de los Derechos de Niños, Niñas y Adolescentes (Act 26.061 on Integral Protection of the Child). ${ }^{125}$ Awaiting a formal and specialised youth justice system, which is the aim of the four-year plan 'Justicia 2020' (infra), these acts are still in force.

Section 1 of Act 22.278 prescribes that children below the age of 16 who commit a criminal offence are not punishable. Likewise, offenders aged 16 or 17 cannot be prosecuted, except when they commit offences that are punishable with prison sentences of two years or more. ${ }^{126}$ The sanction applied is the one that is provided for in the adult PC. ${ }^{127}$ The youth court (which has jurisdiction concerning offences committed by offenders aged 16 or 17 at the time of the offence) $)^{128}$ can also decide not to impose a sentence at all or to reduce the sanction to the penalty that an adult would receive in case of attempt. ${ }^{129}$ Moreover, the sanction imposed can be executed only from the moment that the offender turns 18 and after he or she has been subject to at least one year of 'protective treatment'. ${ }^{130}$ Persons who have reached the age of 18 can be prosecuted for any crime, are fully subject to adult criminal law and are sentenced by the criminal court. ${ }^{131}$

Section 6 of Act 22.278 states custodial sentences (for which there is no maximum duration ${ }^{132}$ ) shall be executed in specialised institutions, but as soon as the offender reaches the age of majority (18) he or she is transferred to adults prisons to serve the rest of the sentence. However, considering the fact that a sanction imposed on an offender who was a minor at the time of the offence can be executed only from the age of 18 , section 6 is without value. The logical explanation for this con-

V-46, https://www.law.kuleuven.be/isr/omgevingsanalyse-volledigrapport-1.

122. Section 27 JGG

123. Abrams et al., above n. 3, at 118; R.M. Pages, 'Infancia, adolescencia, delito y sistema penal en Argentina', 5 Misión Jurídica: Revista de derecho y ciencias sociales 71, at 73 (2012).

124. Act 22.278 of 20 August 1980, Régimen Penal de la Minoridad.

125. Act 26.061 of 29 September 2005, Protección Integral de los Derechos de Niños, Niñas y Adolescentes.

126. Section 2 of Act 22.278

127. A.M. Giorgio and C. López Bernis, Medidas alternativas a la pena de prisión: la probación (2005), at 107.

128. Section 28 Codigo Procesal Penal (Criminal Procedural Code).

129. Ministry of Justice and Human Rights of Argentina, Secretary of Human Rights Argentina and Unicef Argentina, Privados de Libertad. Situación de Niños, Niñas y Adolescentes en la Argentina (2006), at 34; Abrams et al., above n. 3, at 118 .

130. Section 4 of Act 22.278.

131. Abrams et al., above n. 3 , at 119

132. Hazel, above n. 4 , at 62 
tradiction is that section 6 dates from the time that the age of majority was still 21 .

The main problem in the current Argentine legal system is the broad discretion of judges concerning children below the age of 16 (as a remainder of the old theory of the situación irregular). ${ }^{133}$ When those children commit an offence, formally a penalty cannot be imposed because of the legal presumption of lack of criminal responsibility. However, section 1 of Act 22.278 shows that when a minor has been abandoned and is indigent, is in 'material or moral danger' or has behavioural problems, a deprivation of liberty is justified (as a measure of 'protection') until the age of majority (18). ${ }^{134}$ This 'protective confinement' is often used as a hidden punishment. ${ }^{135}$ Act 26.061 had the intention to resolve this problem by making a clear distinction between minors in a vulnerable situation and minors who commit offences, but this practice nevertheless still exists. ${ }^{136}$

At the time of writing this article, Argentina is in a transitional period. As mentioned previously, the Argentine way of dealing with juvenile offenders has been criticised. ${ }^{137}$ Justicia 2020, a project of the ministry of justice aiming to lead to major changes in Argentine legal policy, wants to resolve the criticisms. ${ }^{138}$ The main goals of Justicia 2020 regarding youth justice are the establishment of a separate youth justice system that meets human rights and the provision of an adequate reaction to children in conflict with the law. ${ }^{139}$ In order to reach these goals, Argentina plans to lower the age below which a person cannot be prosecuted from 16 to 15 years old, although 15-year-old offenders could be punished only when they commit a crime that is punishable with a term of imprisonment of fifteen years or more. The old system would continue to exist regarding 16and 17-year-old offenders (i.e. offences that are punishable with prison sentences of two years or more).

\section{Findings: Five Relevant (Clusters of) Age Limits in Youth Justice Systems}

The analysis of age limits in six diverse countries shows that a youth justice system is composed of many more age limits than just a lower and upper limit, which,

133. Abrams et al., above n. 3, at 118.

134. Section 3 of Act 22.278; Ministry of Justice and Human Rights of Argentina, Secretary of Human Rights Argentina and Unicef Argentina, above n. 129, at 34; M. Beloff, 'Los adolescentes y el sistema penal. Elementos para una discusión necesaria en la Argentina actual', 1 Revista Jurídica de la Universidad de Palermo 97, at 102 (2005).

135. Inter-American Commission on Human Rights. Rapporteurship on the Rights of the Child, Justicia juvenil y derechos humanos en las Américas (2011), at 16

136. Section 19 concerning deprivation of liberty and section 27 concerning minimum guarantees.

137. Beloff, above n. 134, at 102

138. https://www.justicia2020.gob.ar/eje-penal/sistema-penal-juvenil/.

139. Ibid. moreover, are not even the same in all circumstances. Five types of age limits can be identified that are relevant to determine how a juvenile offender's offence is reacted upon, some of which can also be subject to derogations. The categories of age limits are first described in neutral terms, using examples from the analysed youth justice systems, and subsequently a specific term and definition are proposed for each type of age limit.

\subsection{Lower Age Limit}

\subsubsection{Findings}

First of all, all six systems appear to have an age below which a minor may under no circumstances be addressed within the framework of youth justice or criminal justice: they cannot be imposed on an offenceoriented reaction due to an irrebuttable presumption of irresponsibility. That lower age limit is fixed at 10 in Northern Ireland and New Zealand, at 12 in the Netherlands, the Flemish Community and Brussels, at 14 in Austria, and at 16 in Argentina. In the French Community of Belgium, on the contrary, the lower age limit remains undefined. The FCD only stipulates that offenders under the age of 12 can be subject to four specific non-custodial reactions, but these possibilities concern reaction age limits (infra under c)) and not the lower age limit of the youth justice system.

The temporal point of reference is always the age at the time of the commission of the offence. However, the terminology used to indicate what is possible once a minor has reached the under age limit, varies widely from one country to another. In the Netherlands, such a minor can be prosecuted, ${ }^{140}$ in Northern Ireland he can become guilty of an offence, ${ }^{141}$ in New Zealand he can be convicted of an offence, ${ }^{142}$ in Brussels he can be responsible for his acts ${ }^{143}$ and in Austria ${ }^{144}$ and Argenti$\mathrm{na}^{145}$ he can be punished from that age onwards. While these systems define a specific consequence of their lower age limit, albeit a different consequence in each one of them, the Flemish Decree does not indicate a specific point of reference. Instead, it links the application of the whole youth justice system to reaching the under age limit, since it states to apply to minors, who are persons between 12 and 18 years old. ${ }^{146}$ As mentioned previously, the FCD is silent on the lower age limit and, as a consequence, on the point of reference as well.

Minors who commit an offence under the specified lower age limit are subject to the national youth welfare law or civil law. Each of the countries requires the minor to be in a state of need (of protection) or to have certain behavioural or psychological problems before one of the welfare or civil measures can be imposed. If so, these measures may even include deprivation of liberty and are, in the worst case, used as a hidden punishment.

140. Art. 486 CCP.

141. Section 3 CJO.

142. Section 21 Crimes Act, No. 43.

143. Art. $17(2)$ CCC statute, a contrario

144. Section 4(1) JCA.

145. Section 1 and 2 Law 22.278 on Youth Justice.

146. Art. 2(10) juncto Art. 4(1) Flemish Decree. 
The latter appears to be the case in Argentina and is considered to be an inevitable consequence of the high lower age limit. ${ }^{147}$ This shows that the establishment of a separate youth justice system and a lower age limit are not sanctifying, nor does it guarantee that no other (implicit) offence-oriented reactions exist. One should therefore not be fixated on age limits, but also, and even more, take account of the consequences. After all, interventions based on another system can be equally intrusive and, moreover, offer a lower level of legal protection.

Since we define the lower age limit as the age following from which it is possible that a minor's offence is reacted upon under youth justice or criminal justice, albeit only for one type of offence, there is no case in which that age limit is lowered any further. It is, however, not inconceivable that minors under that age limit may nevertheless already be the subject of investigative measures under the youth justice system. That can, for example, be the case when the perpetrator of the committed offence is not yet known and the authorities are therefore not aware of his or her age. It is, however, only the Dutch legislature that expresses and regulates this possibility. ${ }^{148}$

In some countries, on the other hand, the lower age limit can be raised depending on the offence committed and/or the moral condition of the minor. Under New Zealand youth justice it is legally possible to prosecute a 10- or 11-year-old, and hence the aforementioned lower age limit of 10 , but only in case of murder or manslaughter and if the minor is aware of the illegality of his behaviour. For serious offences other than murder or manslaughter, the lower age limit is set at 12 years, but the condition of awareness of illegality remains. It is only at the age of 14 that a minor can be prosecuted in any case, regardless of the seriousness of the offence committed or the accountability of the minor. As a consequence, the lower age limit can be raised up to 14 years when none of the two aforementioned conditions are met. In Austria, the lower age limit of 14 can be raised to 16 in case of moderate misdemeanours, i.e. offences for which the minor does not have serious fault and for which there is no need to prevent recidivism through youth justice. In addition, the delayed maturity of a minor can make him indefinitely exempt from prosecution under youth justice, and the minor can therefore in extremis be prosecuted and punished only from the age of 18 , when the criminal justice system principally applies.

\subsubsection{Proposal for Clearer Terminology}

The lower age limit is defined in this article as the age below which an offence-oriented reaction on a minor can under no circumstances be imposed owing to an irrebuttable presumption of irresponsibility. This definition is in line with the requirement of article 40 (3) (a) of the Convention on the Rights of the Child, that the state parties should establish a minimum age below which children shall be presumed not to have the capacity to infringe the penal law. The lower age limit as described in chapter 3.1.1 of this article can therefore be identified as what is generally called the minimum age of criminal responsibility or the MACR. However, we believe that many of the interpretation issues around the MACR arise from the concept itself, which uses the term 'criminal responsibility'. Since all six countries have or are working on a youth justice system that is different from their criminal justice system, the reference to criminal responsibility to define the lower age limit causes confusion. It might be more accurate to use 'the minimum age of youth justice responsibility' (MAYR) as an expression of the lower age limit, since it indicates the moment from when on a minor can be addressed within the framework of youth justice. And even with this refinement, the internal points of reference will still be different: as noted above, prosecution, conviction, guilt, responsibility and punishment are five possibilities, and that only within six analysed countries. In case a youth justice system provides for the possibility to raise the MACR/MAYR related to the type of the committed offence and/or the moral condition of the minor, we introduce the obvious term 'raised MACR/MAYR'.

\section{Minimum age of criminal responsibility (MACR)/ \\ Minimum age of youth justice responsibili- ty (MAYR)}

The age, at the time of the offence, from which on a minor can be imposed an offence-oriented reaction under the youth justice system

Related concept: raised MACR/MAYR

\subsection{Upper Age Limit}

\subsubsection{Findings}

The second traditional age limit set by the countries is the upper age limit of their youth justice system. It is the age from which on a person is, in general, no longer subject to the youth justice provisions but is automatically held accountable under the adult criminal justice system. In all six systems analysed, the upper limit is fixed at the age of 18, which confirms the observation in the international literature that there is more or less an international consensus in this regard. ${ }^{149}$

In the majority of the countries analysed, there is an exception that lowers the upper age limit. In the Netherlands and Belgium, minors can be transferred to the adult criminal justice system from the age of 16 , albeit under strict conditions. Whereas the transfer in the Netherlands concerns only the application of the substantive criminal provisions, and consequently the possible reactions of the youth judge to the committed offence, the transfer in Belgium also implies that the 
minor is tried in accordance with the adult criminal procedure. ${ }^{150}$ In both countries, the decision to transfer a minor to the criminal justice system is at the discretion of the youth judge, except in the case of traffic offences in Belgium, where the transfer takes place automatically. In Northern Ireland and New Zealand, the upper age limit can be lowered all the way down to the lower age limit, which is 10 in both countries. Northern Ireland allows for the application of criminal law provisions to a minor only in the case of homicide or to determine guilt in the case of co-accusation with an adult, after which the minor is remitted to a youth court. Likewise, in New Zealand, minors between 10 and 14 can be tried in accordance with adult criminal law only in case of murder or manslaughter. With regard to minors between 14 and 18 , there is an automatic transfer to the criminal court in four specific cases, and a discretionary decision of the youth court in other (serious) cases. With the exception of the latter case, and contrary to the Netherlands and Belgium, the upper age limit is automatically lowered in these two countries when certain conditions are fulfilled.

Finally, Austria and Argentina do not lower their upper age limit under any circumstances. It is no coincidence that they are also the two countries that adopt the adult criminal sentences in their youth justice system, albeit with some restrictions. The four other countries, in contrast, provide for adapted youth justice measures with relatively low maximum sentences. As a compensation, they use a flexible upper limit, which allows them to invoke criminal justice in serious cases, when no answer can be found within their youth justice system. ${ }^{151}$

As far as raising the upper age limit is concerned, only the Netherlands and Austria have developed a policy regarding young adults who commit an offence after the age of 18. In the Netherlands, the 'adolescent criminal law' applies to persons up to 23 years old, whereas Austria provides for some adaptations for persons who have not reached the age of 21 . It is, however, still the Dutch criminal court and not the youth court that applies these youth justice provisions. The Dutch ACL therefore implies that only the substantive provisions of the youth justice systems are used with regard to young adults, except for the HALT measure and community service. In Austria, on the other hand, the application of youth justice to young adults is restricted to procedural provisions, because young adults are still subject to the range of sentences of adult criminal law. As a consequence, none of the six countries have established a full-fledged young adult justice system.

\subsubsection{Proposal for Clearer Terminology}

As concerns the upper age limit, less confusion exists compared with the lower age limit: the age from which on a person is, in general, held accountable under the adult criminal justice system is unambiguously called the age of criminal majority (ACM). However, in all six

150. J. Put, Handboek Jeugdbeschermingsrecht (2015), at 299. 151. Weijers and Imkamp, above n. 1, at 278. analysed countries, exceptions to the general ACM exist: downwards, upwards or in both directions. The lowering of the ACM, on the one hand, can either be automatic or depend on a judicial decision. That is why we suggest terming this exception 'the advanced ACM', since minors are potentially subject to adult criminal law before they have reached the ACM, which is 18 in these six countries. The raising of the ACM, on the other hand, could be considered a delay in addressing adults under the criminal justice system. This exception could therefore be called 'the delayed ACM'.

\section{Age of criminal majority (ACM)}

The age, at the time of the offence, from which on a person can be imposed an offence-oriented reaction under the criminal justice system

Related concepts: advanced ACM; delayed ACM

\subsection{Lower and Upper Age Limit for Certain Reactions}

\subsubsection{Findings}

Apart from the lower and upper age limit, all six countries have set at least one reaction-based age limit, either an age limit from which certain reactions can be imposed or an age limit until which reactions can last. Three of them have introduced one or more age limits from when a reaction can be imposed, while four of them adopted one or more upper age limits regarding certain reactions.

Whereas in the Netherlands, New Zealand and Austria the general lower age limit of youth justice applies for the imposition of all kind of reactions, Northern Ireland, Belgium and Argentina have set some specific limits. First of all, Northern Ireland sets the minimum age for community services and probation at 16 years. The three Belgian systems introduced a lower age limit regarding custodial sentences, which can be imposed only from the age of 14 (or even 16) onwards, whereas their MACR/MAYR is 12 (or undefined in the French Community). Only exceptionally can a minor be subject to a custodial sentence from the age of 12 , which is the same as the MACR/MAYR in the Flemish Community and Brussels. These higher under age limits show that custodial sentences are given a specific place in the set of possible reactions and confirm the last resort-nature of detention of minors.

In addition, the Brussels' CCC stipulates that working for the purpose of paying damages can be ordered only when the offender has turned 15. The French Community, on the other hand, in which the MACR/ MAYR is undefined, has adopted some implicit reaction-based under age limits. The FCD states that offenders under the age of 12 can be subject only to certain provisional, non-custodial measures, and only to a reprimand as far as final measures are concerned. This means that the age of 12 is the lower age limit for all the other measures. 
Finally, Argentina is a peculiar case: although the lower age limit of youth justice is set at 16 , the reactions imposed are only executable when the offender reaches the age of 18 and after the offender has been subject to at least one year of 'protective treatment'. The result of the protective treatment is taken into account in the decision whether or not to execute the reaction imposed. In other words, a minor, i.e. a person under 18 years old, can never be subject to the execution of an offenceoriented reaction in Argentina. These findings demonstrate that the lower age of youth justice is not all-inclusive or determinative and needs to be complemented with other age limits.

As to the upper age limit for reactions, the Flemish Community in particular, has a striking feature. Its general upper age limit is set at 23 , but there is a specific age limit for custodial sentences. Long detention can be applied until the age of 25 , and in combination with preventive custody of 10 years, an offender who was a minor at the time of the offence can even be detained until the age of 35 . In other words, this custodial sentence can last until the offender is almost twice as old as the ACM of the Flemish Community, which is 18.

Another example that shows that not only the lower and upper age limits of youth justice are important is Austria. Austria provides four different upper ages for custodial sentences - 18, 22, 24 and 27 - as an ultimate upper limit. In the Netherlands, the maximum duration of a PIY-measure (which is also a custodial sentence) is seven years, which means the offender can be detained until he or she is 30 years old in case the ACL system is applied. Similar to the systems of the Flemish Community and Austria, the upper age limit of custodial reactions is rather high compared with the ACM (18), which points out, once again, the special nature of these reactions.

New Zealand, on the other hand, is rather consistent: apart from the ACM, which is 18 , the upper age limit for reactions (custodial sentences included) is 19. As a consequence, supervision with residence orders has a short and limited duration. In order to cope with this low age-border that separates children from adults, serious offences committed by a minor are tried in adult court, where his young age can be considered as a mitigating circumstance.

In the French Community and in Brussels a distinction in age limits is made between provisional and final measures. In both regions the provisional measures end at the age of 20 and the final measures expires at the age of 18, with an exception upwards (20 in the French Community and 23 in Brussels). A reprimand can be imposed at any age.

\subsubsection{Proposal for Clearer Terminology}

These findings demonstrate that a youth justice system cannot be reduced to a system consisting of a lower and an upper limit and that the duo MACR/MAYR and ACM is an unsatisfactory dichotomy. The foregoing examples show that the under and upper age limits for certain reactions are influential as well. This third type of age limits has been unexplored territory until now. ${ }^{152}$ Because of the relevance of this category of age limits in legal practice, it should be recognised as a distinct and individual age limit. The age limit for certain reactions can be unified in one comprehensive term, namely the 'reaction age limit' (RAL). The lower age limit for certain reactions should be called the 'lower reaction age limit (lower RAL)', whereas for the upper age limit for certain reactions the label 'upper reaction age limit (upper RAL)' is suitable.

\section{Reaction age limits (RAL)}

Related concept: Lower RAL The age, at the time of the offence, from which on a certain offence-oriented reaction can be imposed to a minor under the youth justice system

Related concept: Upper RAL

The age, at the time of the execution of the reaction, until which offence-oriented reactions last under the youth justice system

\subsection{Age Categories Within Reactions}

\subsubsection{Findings}

Now that we have discussed the reaction-based lower and upper age limits, a fourth age category arises. Five out of the six countries examined have adopted certain age limits within reactions.

The Netherlands, Northern Ireland, the Flemish Community and Austria have set up a layered system for custodial sentences depending on the age of the offender. In the Netherlands minors between the age of 12 and 16 can be subject only to a custodial sentence of twelve months, whereas on offenders aged 16 or older a custodial sentence with a maximum duration of 24 months can be imposed. The same goes for Austria: children aged 14 but less than 16 can get a custodial sentence with a maximum duration of ten years, while offenders aged 16 and 17 can be subject to sentences of fifteen years. In Northern Ireland the maximum duration of a custodial sentence for children between 10 and 17 years is two years, whereas there is no maximum duration for offenders aged 17 until 21. The 'long detention' system of the Flemish Community consists of three layers: a duration of a maximum of two years for minors aged 12 and 13, a maximum of five years for minors aged 14 and 15 and a maximum of seven years for minors 16 or 17 years old.

In Northern Ireland and New Zealand, on the other hand, the amount of the payments and/or the person who needs to pay varies according to the age of the offender. In Northern Ireland, children aged 10 to 14 who committed an offence do not have to pay a fine themselves; instead, their parent or guardian should. Once children have reached the age of 14 , the amount of

152. For an overview of the age limits for custodial sentences in Europe: Dünkel et al., above n. 2, at 1793. 
the fine increases. Minors between the age of 16 and 18, finally, have to pay the fine themselves. Similarly, in New Zealand minors only have to pay the costs of the prosecution themselves from the age of 16. Regarding minors between the age of 10 but less than 16 the parents have to pay these costs.

\subsubsection{Proposal for Clearer Terminology}

The fact that youth justice systems are 'layered', meaning that the weight or height of certain measures depends on the age of the offender at the time of the offence, shows once again that several subcategories of age limits exist within a youth justice system, between the two extreme age limits that define its scope. Connecting the age of an offender to certain consequences (the degree or duration of sentencing) allows systems to respond to the degree of maturity and responsibility of the offender. Age limits of this type can be called the internal age limits of reactions (IALR).

\section{Internal age limits of reactions (IALR)}

The age, at the time of the offence, which determines the degree or duration of the offence-oriented reaction that can be imposed on a minor under the youth justice system

\subsection{Competent Court and Detention Institutions Depending on Age}

\subsubsection{Findings}

The final category of age limits concerns a more procedural part, namely the jurisdiction of the existing actors in youth justice. This category can be divided into two subcategories: the competent court (trial), on the one hand, and the competent services and institutions (execution), on the other hand.

Following the upper age limit of youth justice (18 in all the systems discussed), an offender who had not reached the age of 18 at the time of the offence is tried in youth court (and sentenced according to youth justice law), while offenders of at least 18 years of age at the time of the offence are sentenced in adult court based on the provisions of criminal law. However, only in Argentina does this rule apply unexceptionally. In the other countries, two types of exceptions exist to this general rule: (1) the trial of an offender under the age of 18 in criminal court because of a transfer and (2) the trial of an offender aged 18 in adult court according to youth justice law or the trial of an offender under the age of 18 in youth court according to criminal law.

The most common exception is the transfer system. Three of the countries examined, namely Northern Ireland, New Zealand and Belgium, have introduced a procedure in which a minor can be tried in criminal court according to criminal law. In Northern Ireland this is possible from the age of 10 in the case of homicide or co-accusation with an adult (although the sentencing of the co-accused minor occurs in youth court according to youth justice law), whereas in all Belgian systems only minors who are at least 16 years old at the time of the offence and commit a traffic offence are automatically tried in the adult criminal court according to criminal law. In New Zealand, children between the age of 10 and 14 are automatically transferred to the adult court when they are charged with murder or homicide. Regarding young persons (14-18 years old), the trial automatically takes place in adult court in certain cases (automatic transfer), while in other cases the youth court has the power to decide whether or not to transfer (judicial transfer).

The second exception to the general rule can be found in the Netherlands and in Belgium. The provisions of criminal law exceptionally apply to offenders aged 16 and 17 , but only concerning the reactions available (substantive law). It is the youth court that remains competent to try these minors (procedural law). In the Netherlands the exception also applies the other way around, meaning that young adults (18-23 years old) are tried in criminal court according to youth justice law. In that sense this category is more a nuance than an actual exception, because it only adopts the substantive reaction possibilities of the age-appropriate system and not its procedure. However, in Belgium even this nuance has to be nuanced: those 16- and 17-year-olds can be tried only by a specialised non-permanent chamber of the youth court with both criminal judges and judges with expertise of youth justice law. ${ }^{153}$ Considering that this chamber is non-permanent and criminal judges also participate, the chamber lies somewhere in between the youth and adult court.

Lastly, the competent detention institutions vary depending on the age of the offender, which must be, contrary to the other age limits, generally determined at the time of the execution. The analysis examined the age limits of only final custodial sentences, therefore excluding remand in custody or mediation services. While one would presume that minors are detained in specialised youth institutions but transferred to adult prison once they attain the age of 18 , this presumption can be rebutted. Again with the exception of Argentina, the analysis of the countries shows that several exceptions to this (alleged) general rule exist.

Apart from Belgium, where juvenile offenders remain in youth institutions for the whole duration of the imposed reaction, the competent detention institution often relates to the upper age limit for custodial sentences (which is mostly higher than the ACM and the upper RAL). The ACL system in the Netherlands, for example, allows offenders to be held in young offenders institutions until the age of 23. Likewise, offenders can be detained in an Austrian institution for youth detention until the age of 27. In Northern Ireland, juvenile offenders are detained in a juvenile justice centre or a young offenders centre, depending on the type of custodial sentence. Once he or she has reached the age of 21 , the judge can decide whether or not to transfer him or her to an adult prison. The age of 24 is the ultimatum;

153. Serious offences will be dealt with in the court of assizes. 
offenders are then automatically transferred to adult prison.

In New Zealand, to the contrary, the competent detention institution relates to the transfer system (causing a trial in adult court with adult sentences), as described previously. More specifically, both children as young persons are usually detained in a youth justice residence, but young persons can also be sent to prison in case a transfer to the criminal justice system has occurred.

\subsubsection{Proposal for Clearer Terminology}

These last age limits can be named the 'court age limits' (CAL) and the 'detention institutions age limits' (DIAL), all together called the 'actors age limits' (AAL). The CAL is mainly a combination of the potential ACM, the (general) ACM and the delayed ACM. The DIAL, on the other hand, is, next to the aforementioned combination, influenced by the general, lower and upper RAL and the lower and upper RALs of custodial sentences. Nevertheless, both the CAL and the DIAL are distinct age limits with their own characteristics and purpose. Defining those age limits is therefore a way to emphasise their individuality and contributes to the conceptual coherence in youth justice.

\section{Actors age limits (AAL)}

Related concept: Court age limits (CAL)

The age, at the time of the offence, which determines the competent court in which a person will be tried

Related concept: Detention institution age limits (DIAL)

The age, at the time of the execution of the reaction, which determines the competent detention institution in which a person will be detained

\section{Conclusion}

This article, first of all, demonstrates that the distinction between the MACR and ACM is too general, considering the finesse and layers that are to be found in youth justice systems. More specifically, it is shown that this traditional pair must be completed with three other types of age limits. In the end, youth justice systems can consist of five clusters of age limits: the (raised) minimum age of criminal/youth justice responsibility (MACR/MAYR), the (advanced and delayed) age of criminal majority (ACM), the (lower and upper) reaction age limits (RAL), the internal age limits of reactions (IALR) and the actors age limits (AAL), which consist of the court age limits (CAL) and the detention institution age limits (DIAL). Each type of age limit has its own impact on the youth justice system and its own consequences with regard to the juvenile offender, which are displayed in the table in Section 5.

Apart from raising awareness of those other influential age limits, this article clarifies the meaning of the
MACR. Owing to the long-standing ill-defined nature of this notion, different interpretations have arisen in several countries. The ensuing practical implications of this issue cannot be underestimated, as it is a key concept in children's rights. Therefore, we created a new term, which is more suitable and avoids confusion: the minimum age of youth justice responsibility (MAYR). Nevertheless, the value of the MACR/MAYR can also not be overestimated. The other age limits discussed prove that the main focus of the academic world on, and the importance of, the MACR/MAYR is slightly exaggerated.

Another reason for confusion and haziness in the field of age limits that is detected in this article is the lack of attention concerning the moment upon which the person must have reached the age limit. It is often unclear whether the criterion is the age at the time of the offence, the age at the time of the judgment or the age at the time of the execution of the reaction. The age at the time of the offence is the most common momentum, since it is the general criterion for the MACR/MAYR, ACM, lower RAL, internal age limit of reactions and CAL. This consistency is remarkable, but probably owing to the attention of the international institutions in children's rights on this criterion. ${ }^{154}$ The lower RAL in Argentina (age at the time of the execution of the reaction) and the internal age limit of reactions concerning fines in Northern Ireland (age at the time of the judgment) show that this rule is also not free from exceptions.

Furthermore, this article wants to give an incentive to examine age limits in systems other than youth justice, as such systems can equally influence the way in which the criminal behaviour of a minor is reacted upon. On the one hand, all six systems seem to have introduced a practice of dealing with child offenders who have not yet reached the MACR/MAYR under some type of youth welfare or civil law. The underlying idea of these systems is the same: a child can be subject to such a youth care system only if it finds him- or herself in some kind of problematic situation ('growing and parenting problems, psychological problems and disorders', 'in need', 'likely to suffer significant harm', etc.) However, this theoretical basis on which the youth care system comes into effect may be used differently in practice. For example, in Argentina, children the age of 16 who commit an offence are not punishable but are frequently detained on the basis of youth care provisions. Despite a high MACR/MAYR, the youth care system in Argentina is thus often used to deal with impunity. In conclusion, the table in the next section illustrates the theoretical age limits but does not take into account practical deviations.

On the other hand, the analysis focuses only on 'offence-oriented reactions' and explicitly excludes reactions in administrative law, even though custodial reactions can be imposed under such systems as well. Examining reactions imposed under youth care, civil or

154. UN Committee on the Rights of the Child, above n. 5, at 9-10. 
administrative legislation would therefore certainly be a valuable extension of our preliminary study.

Finally, this analysis is limited to six countries, which is obviously too small a number to be able to make firm conclusions. Although these countries are carefully selected on the basis of varied characteristics (European versus non-European, alleged low versus high MACR/ MAYR, etc.), a study of six youth justice systems cannot be generalised without further research in other countries. We therefore strongly encourage the expansion of this experimental study and continued research regarding the different age limits in different countries in order to refine our proposed conceptual framework.

\section{Table: An Overview of the Five Clusters of Age Limits in Six Countries}

The following table is a visualisation of the several distinguished age limits and the newly proposed names, albeit in a simplified way. More information on the possible exceptions and nuances can be found in the country analyses in chapter 2 of this article.

The following abbreviations are used in the table: Flemish Community (Fl), French Community (Fr), Brussels (Br), exceptionally (exc.), juvenile justice centre order (JJCO), custody care order (CCO), time of the judgment $(\mathrm{J})$, time of the execution of the judgment $(\mathrm{E})$. 


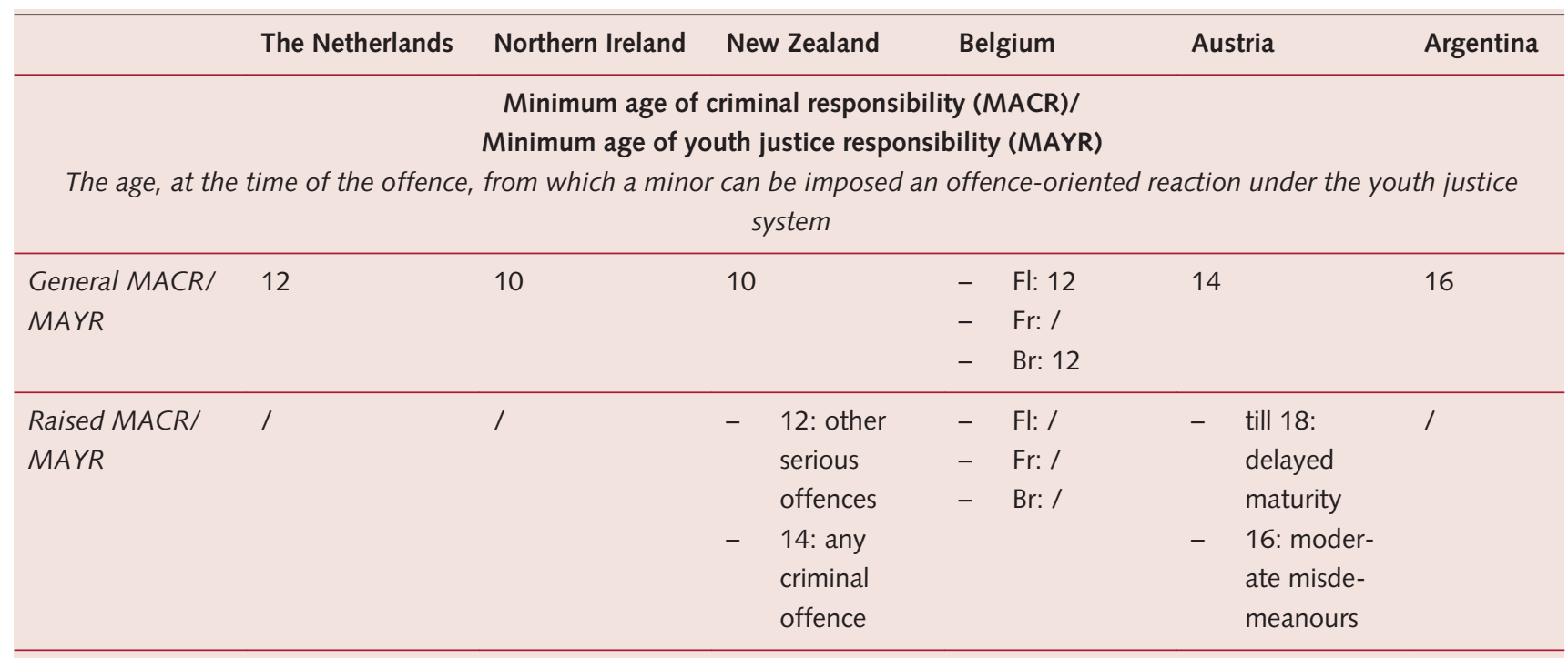

Age of criminal majority (ACM)

The age, at the time of the offence, from which a person can be imposed an offence-oriented reaction under the criminal justice system

\begin{tabular}{|c|c|c|c|c|c|c|c|}
\hline General ACM & 18 & 18 & 18 & & $\begin{array}{l}\text { Fl: } 18 \\
\text { Fr: } 18 \\
\text { Br: } 18\end{array}$ & 18 & 18 \\
\hline Advanced ACM & $\begin{array}{l}16 \text { (only substan- } \\
\text { tive provisions) }\end{array}$ & 10 in two cases & 10 & $\begin{array}{l}- \\
- \\
-\end{array}$ & $\begin{array}{l}\text { Fl: } 16 \\
\text { Fr: } 16 \\
\text { Br: } 16\end{array}$ & I & I \\
\hline Delayed ACM & $\begin{array}{l}23 \text { (only substan- } \\
\text { tive provisions) }\end{array}$ & / & I & - & $\begin{array}{l}\mathrm{Fl}: / \\
\mathrm{Fr}: / \\
\mathrm{Br}: /\end{array}$ & $\begin{array}{l}21 \text { (only proce- } \\
\text { dural provisions) }\end{array}$ & / \\
\hline
\end{tabular}

\section{Lower reaction age limits (Lower RAL)}

The age, at the time of the offence, from which a certain offence-oriented reaction can be imposed on a minor under the youth justice system

\begin{tabular}{|c|c|c|c|c|c|c|c|c|}
\hline $\begin{array}{l}\text { Custodial sen- } \\
\text { tence }\end{array}$ & / & / & & / & $\begin{array}{l}- \\
- \\
- \\
- \\
-\end{array}$ & $\begin{array}{l}\text { Fl: 14/16 } \\
\text { (exc. 12) } \\
\text { Fr: } 14 \\
\text { (exc. 12) } \\
\text { Br: } 14 \\
\text { (exc. 12) }\end{array}$ & I & I \\
\hline Other reactions & I & $\begin{array}{l}- \\
- \\
-\end{array}$ & $\begin{array}{l}\text { community } \\
\text { service: } 16 \\
\text { (J) } \\
\text { probation: } \\
16\end{array}$ & I & - & $\begin{array}{l}\text { Fl: / } \\
\text { Fr: } 12 \\
\text { (except } 3 \\
\text { reactions } \\
\text { under the } \\
\text { age of 12) } \\
\text { Br: work to } \\
\text { pay } \\
\text { damages: } 15\end{array}$ & I & $\begin{array}{l}\text { general: } 18 \\
\text { (E) }\end{array}$ \\
\hline
\end{tabular}




\begin{tabular}{|c|c|c|c|c|c|c|}
\hline & The Netherlands & Northern Ireland & New Zealand & Belgium & Austria & Argentina \\
\hline \multicolumn{7}{|c|}{ Upper reaction age limits (Upper RAL) } \\
\hline General & / & / & 19 & 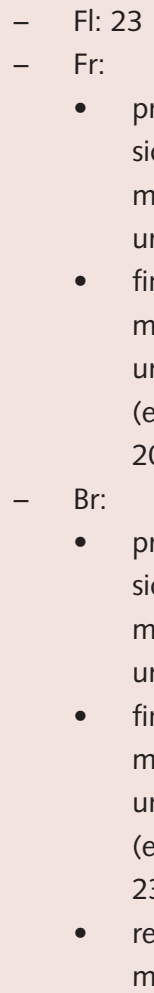 & / & / \\
\hline $\begin{array}{l}\text { Custodial sen- } \\
\text { tence }\end{array}$ & $\begin{array}{l}30 \text { in case of } \\
\text { extended PIY- } \\
\text { measure }\end{array}$ & / & 19 & $\begin{array}{ll}\text { - } & \text { Fl: } 35 \\
\text { - } & \text { Fr: / } \\
\text { - } & \text { Br: / }\end{array}$ & $\begin{array}{l}18,22,24 \text { or } 27 \\
\text { depending on } \\
\text { certain conditions }\end{array}$ & / \\
\hline
\end{tabular}

Internal age limits of reactions (IALR)

The age, at the time of the offence, which determines the degree or duration of the offence-oriented reaction that can be imposed on a minor under the youth justice system

\begin{tabular}{|c|c|c|c|c|c|c|c|c|c|c|c|}
\hline $\begin{array}{l}\text { Maximum dura- } \\
\text { tion of custodial } \\
\text { sentence }\end{array}$ & - & $\begin{array}{l}\text { 12-16: } 12 \\
\text { months } \\
\text { 16-17: } 24 \\
\text { months }\end{array}$ & - & $\begin{array}{l}\text { 10-17: } 2 \\
\text { years } \\
\text { 17-21: / }\end{array}$ & I & & - & $\begin{array}{ll}\text { Fl: } & \\
\text { - } & \text { 12-13: } \\
& 2 \text { years } \\
\text { - } & \text { 14-15: } \\
& 5 \text { years } \\
\text { - } \quad \text { 16-17: } \\
\\
7 \text { years } \\
\mathrm{Fr}: / \\
\mathrm{Br}: /\end{array}$ & $\begin{array}{l}- \\
-\end{array}$ & $\begin{array}{l}\text { 14-16: } 10 \\
\text { years } \\
\text { 16-17: } 15 \\
\text { years }\end{array}$ & I \\
\hline Other reactions & l & & - & $\begin{array}{l}\text { 10-14 }(\mathrm{J}) \text { : } \\
\text { lower fines, } \\
\text { paid by } \\
\text { parent or } \\
\text { guardian } \\
\text { 14-18 }(\mathrm{J}) \text { : } \\
\text { higher fines, } \\
\text { paid by } \\
\text { parent or } \\
\text { guardian } \\
\text { 16-18 }(\mathrm{J}) \text { : } \\
\text { higher fines, } \\
\text { paid by } \\
\text { minor }\end{array}$ & $\begin{array}{l}- \\
- \\
-\end{array}$ & $\begin{array}{l}\text { 10-16: order } \\
\text { to pay costs } \\
\text { of prosecu- } \\
\text { tion paid by } \\
\text { parents } \\
\text { 16-18: order } \\
\text { to pay costs } \\
\text { of prosecu- } \\
\text { tion paid by } \\
\text { minor }\end{array}$ & $\begin{array}{l}- \\
- \\
-\end{array}$ & $\begin{array}{l}\mathrm{Fl}: / \\
\mathrm{Fr}: \text { / } \\
\mathrm{Br}: /\end{array}$ & I & & I \\
\hline
\end{tabular}




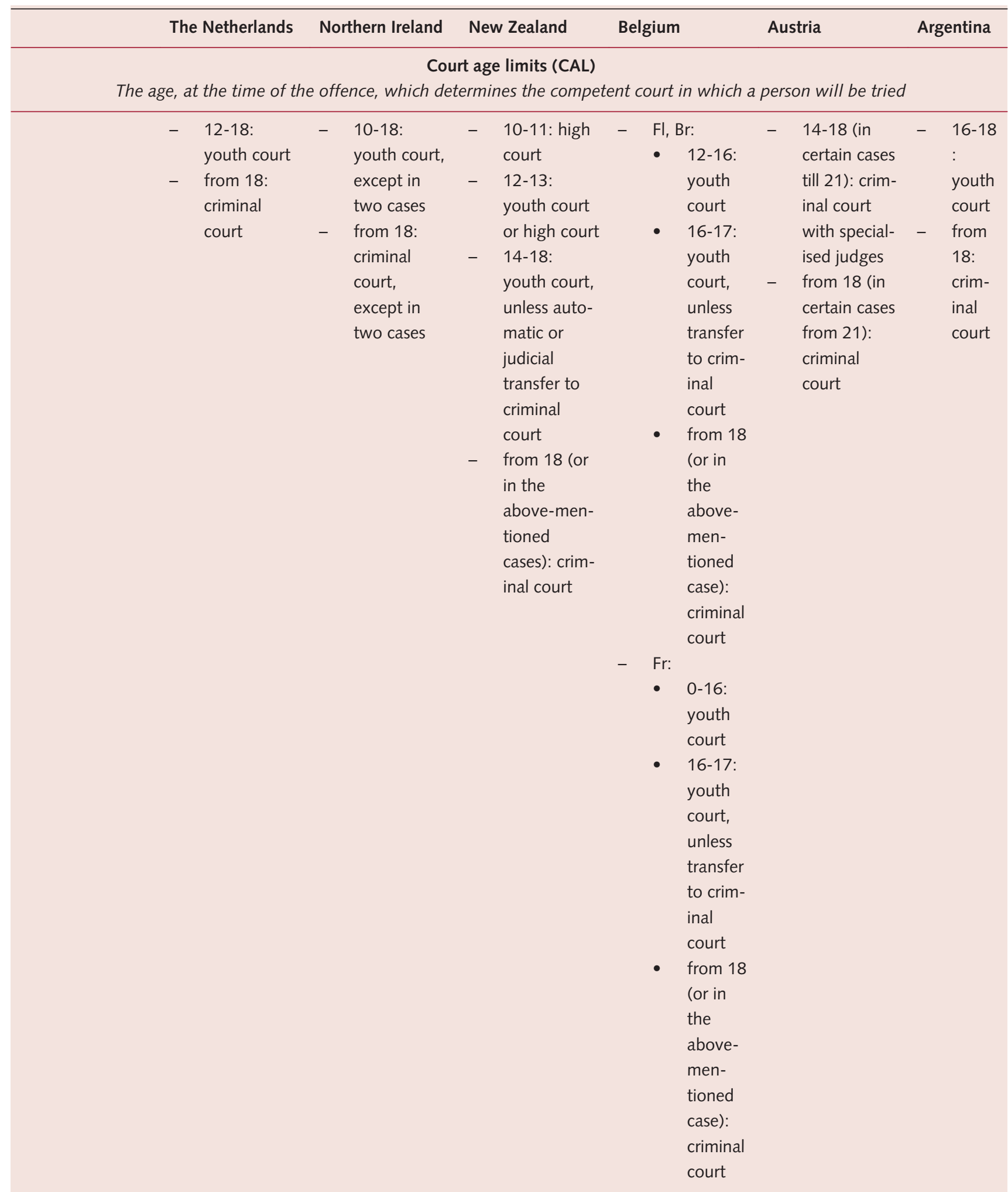




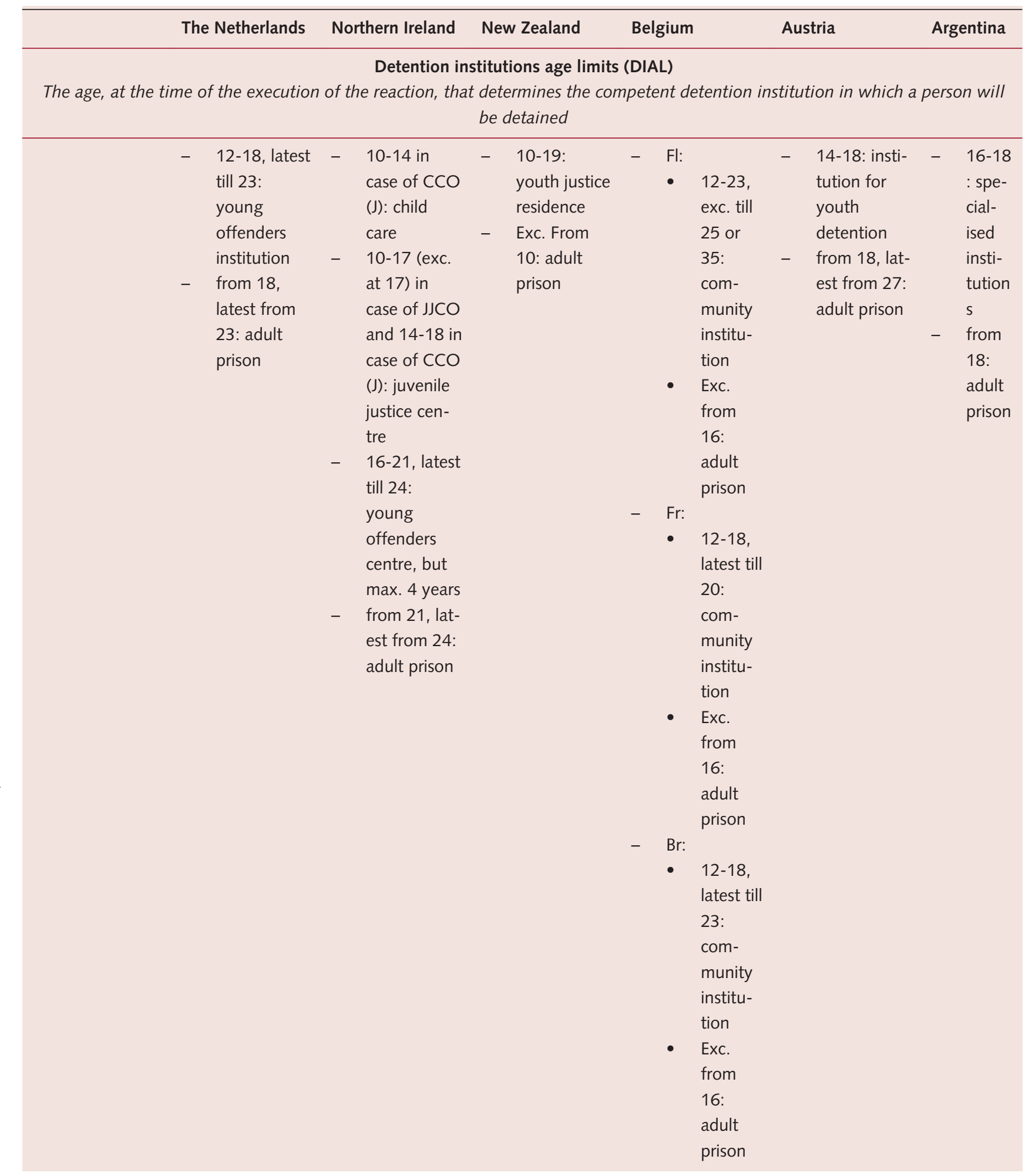

